\title{
ISOLATION AND SELECTION OF EPIPHYTIC YEAST FOR BIOCONTROL OF Botrytis cinerea PERS. ON TABLE GRAPES
}

\author{
Marisol Vargas ${ }^{1 *}$, Felipe Garrido ${ }^{1}$, Nelson Zapata ${ }^{1}$, and Maritza Tapia ${ }^{1}$
}

\begin{abstract}
Botrytis cinerea Pers., the causal agent of gray mold, infects more than 200 plant species. This pathogen has traditionally been controlled by fungicides. However, with the increasing demand for pesticide-free foods new control strategies are needed. The objective of this study was to isolate and select grapevine (Vitis vinifera L.) epiphytic yeasts for the biocontrol of $B$. cinerea in table grapes. Of the total isolated yeasts $(n=256), 32$ exhibited mycelial growth inhibition in dual cultures with a halo $>4 \mathrm{~mm}$, and eight of these isolates inhibited $>90 \%$ of conidial germination. When evaluating increasing concentrations on conidial germination inhibition, a dose-dependent response was observed with $\mathrm{EC}_{90}$ values from $0.45 \times$ $10^{5}$ to $0.22 \times 10^{8}$ cells $\mathrm{mL}^{-1}$. The antagonistic activity of six yeasts against B. cinerea in table grape berries 'Flame Seedless' increased as the yeast colonization time increased from 1 to $24 \mathrm{~h}$ on the berries, resulting in a higher biocontrol activity on $B$. cinerea. These results show the effectiveness of grapevine epiphytic yeasts as biocontrol agents of $B$. cinerea on table grapes.
\end{abstract}

Key words: Gray mold, antagonistic yeast, biocontrol agents, Vitis vinifera.

$B$ otrytis cinerea Pers., the causal agent of gray mold, is a fungus affecting more than 200 plant species worldwide (Elad et al.,2007), and this disease is considered a limiting factor for exporting table grapes (Vitis vinifera L.) in Chile (Latorre, 2007). Botrytis cinerea affects the vine's non-lignified aerial organs, such as leaves, buds, rachis, and flowers, causing tissue necrosis and soft rot of the berries (Benito et al., 2000; Holz et al., 2003; Latorre, 2004; Agrios, 2005; Elad et al., 2007; Williamson et al., 2007). This fungus generates abundant mycelia and produces a great quantity of conidia at the end of branched conidiophores. In adverse conditions also generates survival structures, known as sclerotia. Furthermore, it can survive as saprophyte on plant residues during the winter. Conidia can persist as latent inoculum in floral residues, such as stamens and calyptrae causing postharvest rot (Latorre, 2004; Viret et al., 2004).

Traditionally, the control of $B$. cinerea has been based on synthetic fungicides (Latorre et al., 2001; Serey et al., 2007). However, pathogen resistance has appeared because of the irrational use of these products (Latorre et al., 2002; Esterio et al., 2007) which leads to less control effectiveness. Furthermore, there is public concern about decreasing fungicide residues in foods and the environment, which is a limiting factor for this type of pesticide.

${ }^{1}$ Universidad de Concepción, Facultad de Agronomía, Av. Vicente Méndez 595, casilla 537, Chillán, Chile.

"Corresponding author (marisolvargas@udec.cl).

Received: 19 October 2011.

Accepted: 3 May 2012.
The use of biopesticides based on beneficial microorganisms appears as an interesting alternative to control B. cinerea (Zahavi et al., 2000; Spadaro and Guillino, 2003; Elmer and Reglinski, 2006; Chanchaichaovivat et al., 2007; Sharma et al., 2009). Yeasts are leading the advances to control pathogens causing fruit rot (McLaughlin et al., 1990; Droby et al., 1998; Spadaro et al., 2002; Vero et al., 2002; Chanchaichaovivat et al., 2007). Several studies have demonstrated an efficient antagonistic activity of yeast against B. cinerea (Saligkarias et al., 2002; Santos et al., 2004; Elmer and Reglinski, 2006; Dal Bello et al., 2008).

Given the importance of gray mold in Chile and the associated management problems, the objective of this study was to isolate and select grapevine epiphytic yeasts to evaluate its effectiveness to control $B$. cinerea on table grapes.

\section{MATERIALS AND METHODS}

\section{Grape sample collection}

The plant material was collected in March 2009 in the Coquimbo Region, Chile, at three commercial orchards with traditional management. 'Thompson Seedless' grapes were picked from the Almendro 4 sector of "La Granja" farm belonging to Del Monte company (3040'41.5" $\mathrm{S}$, $71^{\circ} 20^{\prime} 31.2$ " W, $200 \mathrm{~m}$ a.s.1.); 'Red Globe' grapes from the Almendro 11 sector in the same farm $\left(30^{\circ} 44^{\prime} 37.8^{\prime}\right.$ ' $\mathrm{S}$, $71^{\circ} 20$ '01.7"W, 217 ma.s.1.); and 'Moscatel de Alejandría'

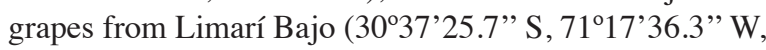
$166 \mathrm{~m}$ a.s.1.). To collect samples, 40 plants were selected from each sector; two healthy clusters were cut from 
each plant, placed into plastic bags, labeled, and stored in cooled thermal containers for transport. Fruit infected with $B$. cinerea were also obtained from the same sectors and stored under the above mentioned conditions.

\section{Yeast and $B$. cinerea isolation and inoculum production} Yeast isolates were obtained from the healthy fruit epidermis following the methodology described by Rabosto et al. (2006). Five berries from each cluster were washed for $30 \mathrm{~s}$ with $10 \mathrm{~mL}$ of saline solution $(9 \mathrm{~g}$ $\mathrm{NaCl}$ in $1 \mathrm{~L}$ sterile distilled water). The resulting solution was diluted (1:10), and $50 \mu \mathrm{L}$ were sown on Petri dishes containing a minimal sterile yeast-extract peptone dextrose (YPD min) medium (5 g dextrose, $3 \mathrm{~g}$ yeast extract, $5 \mathrm{~g}$ peptone, $18 \mathrm{~g}$ agar, and $1 \mathrm{~L}$ distilled water) supplemented with $0.05 \mathrm{~g} \mathrm{~L}^{-1}$ streptomycin (Sigma-Aldrich), $0.05 \mathrm{~g} \mathrm{~L}^{-1}$ chloramphenicol (Sigma-Aldrich), and adjusted to $\mathrm{pH}$ 4.6. These were incubated at $25^{\circ} \mathrm{C}$ until the development of the microorganism colonies in the culture medium was observed. Yeast colonies were isolated and cultured in YPD medium (20 $\mathrm{g}$ dextrose, $20 \mathrm{~g}$ peptone, $10 \mathrm{~g}$ yeast extract, $20 \mathrm{~g}$ agar, and $1 \mathrm{~L}$ distilled water). Finally, isolates were inoculated in tubes with inclined YPD medium and stored at $4{ }^{\circ} \mathrm{C}$ for subsequent analysis.

For inoculum production, yeasts were activated in 10 $\mathrm{mL}$ of glucose-yeast extract-peptone broth medium (GYP broth; $5 \mathrm{~g}$ glucose, $3 \mathrm{~g}$ yeast extract, $5 \mathrm{~g}$ peptone, and $18 \mathrm{~g}$ agar per liter) in $250 \mathrm{~mL}$ flasks on a rotary shaker at $100 \mathrm{rpm}$ at $25^{\circ} \mathrm{C}$ for $72 \mathrm{~h}$. Cells were harvested by centrifugation $(5000 \mathrm{rpm}, 10 \mathrm{~min})$, washed twice with sterile deionized water, and resuspended in water. Suspensions were adjusted to the desired concentration in a Neubauer chamber.

Botrytis cinerea was isolated from grape berries 'Red Globe'. Pathogen conidia were sown on dishes with potato dextrose agar medium (PDA) (Difco) and incubated at 25 ${ }^{\circ} \mathrm{C}$. Pure cultures were obtained with hyphal tips from the edges of mycelial growth and monosporic cultures were obtained from reproductive structures. The monosporic cultures were placed in tubes with PDA medium and kept at $4{ }^{\circ} \mathrm{C}$. For the inoculum production, a $5 \mathrm{~mm}$ diameter disk of actively-growing mycelia was cut from the monosporic culture and placed on a dish containing YPD medium, 12 to $15 \mathrm{~d}$ before each assay. When the reproductive structure formation was observed in the medium, $10 \mathrm{~mL}$ of saline solution was added to each dish, the conidia were removed with a glass rod, and the contents filtered through cloth gauze. A suspension of the pathogen conidia was prepared with a $1 \times 10^{6}$ conidia $\mathrm{mL}^{-1}$ concentration in a Neubauer chamber.

\section{Selection of yeast with inhibitory activity on $B$. cinerea mycelial growth}

The in vitro dual culture technique was employed to determine the degree of inhibition of the yeast isolates against $B$. cinerea mycelial growth. Mycelial disks of
$5 \mathrm{~mm}$ diameter from actively growing culture were cut from the $B$. cinerea monosporic isolate. Each disk was placed in the center of a Petri dish with malt extract agar (MEA) (Difco) medium and incubated at $25{ }^{\circ} \mathrm{C}$ for $24 \mathrm{~h}$. Yeast isolates were inoculated on four perpendicular lines to the center of the fungus growth. A mycelial disk of the pathogen growing without yeast was the control. Cultures were incubated at $25^{\circ} \mathrm{C}$ for $7 \mathrm{~d}$.

The level of mycelial growth inhibition was determined by the Swadling and Jeffries (1996) scale: $0=$ without any visible signs of $B$. cinerea inhibition, mycelium surpasses antagonist colony; 1 = both organisms stop growing on contact; $2=$ inhibition zone between pathogen and antagonist is $<2 \mathrm{~mm} ; 3=$ inhibition zone is 2 to 4 $\mathrm{mm}$; and $4=$ inhibition zone is $>4 \mathrm{~mm}$. All yeast isolates reaching a value of 4 on this scale were selected for the next bioassay.

\section{Inhibitory effect of yeast isolates on $\boldsymbol{B}$. cinerea conidial germination}

An assay was established to select yeasts with antagonistic activity on $B$. cinerea conidial germination at two temperatures $\left(5\right.$ and $25^{\circ} \mathrm{C}$ ) according to the methodology described by Zhang et al. (2007). A volume of $100 \mu \mathrm{L}$ of suspended yeast $\left(1 \times 10^{8}\right.$ cells $\left.\mathrm{mL}^{-1}\right)$ and $100 \mu \mathrm{L}$ suspended pathogen conidia $\left(1 \times 10^{6}\right.$ conidia $\left.\mathrm{mL}^{-1}\right)$ were added to an Eppendorf tube containing $800 \mu \mathrm{L}$ malt extract broth (MEB) (Difco) medium. The suspended yeast was replaced by $100 \mu \mathrm{L}$ of sterile distilled water in the control treatment. Three replicates were carried out for each treatment (yeast). Tubes were incubated for $24 \mathrm{~h}$ at $25^{\circ} \mathrm{C}$ and $72 \mathrm{~h}$ at $5{ }^{\circ} \mathrm{C}$. Subsequently, 100 conidia were counted for each replicate and the number of germinated conidia was determined. The germination criterion considered that conidium was germinated when the length of the germination tube was more than twice the greatest spore diameter. The conidial germination inhibition index (GII \%) was calculated from the results according to the formula described by Manici et al. (1997), where GII (\%) $=($ conidia germinated in control - conidia germinated in treatment) $\times 100 /$ conidia germinated in control. Yeast isolates with a GII (\%) greater than $90 \%$ at 5 and $25{ }^{\circ} \mathrm{C}$ were selected for the next bioassays.

\section{In vivo yeast pathogenicity}

To determine if yeast selected in the previous assay are pathogenic in grapes, $15 \mu \mathrm{L}$ suspended yeast $\left(1 \times 10^{8}\right.$ cells $\mathrm{mL}^{-1}$ ) were inoculated in a micro-wound made on grape berries 'Flame Seedless' that were homogeneous in size and 16.5 to $17.7^{\circ}$ Brix. These berries were previously disinfected with a commercial sodium hypochlorite solution (Clorinda ${ }^{\circledR}$ ) at $5 \% \mathrm{v} / \mathrm{v}$ for $5 \mathrm{~min}$. They were placed in $250 \mathrm{~cm}^{3}$ plastic containers at $25{ }^{\circ} \mathrm{C}$ for $7 \mathrm{~d}$ and incubated. It was determined that the yeast was pathogenic when an alteration of the berry tissue was observed. 


\section{Effect of yeast concentration and colonization time}

Yeast selected in the previous assay, which were nonpathogenic were activated in the above mentioned culture medium and adjusted in $1 \times 10^{5}, 1 \times 10^{6}, 1 \times 10^{7}$, and $1 \times 10^{8}$ cells $\mathrm{mL}^{-1}$ concentrations. The methodology was the same as the one described for the conidial germination inhibition assay. Three replicates per treatment were established. The GII $(\%)$ and $90\left(\mathrm{EC}_{90}\right)$ effective concentration of $B$. cinerea conidial germination inhibition were determined.

To determine the effect of yeast colonization time on grape berry wounds on the biocontrol activity of gray mold, homogeneous-sized grape berries 'Flame Seedless' were disinfected as described above and four evenly spaced micro wounds were made in the equatorial zone with a sterile needle. They were then submerged in a selected $1 \times 10^{8}$ cells $\mathrm{mL}^{-1}$ yeast suspension for $20 \mathrm{~s}$. Each treatment (yeast) consisted of 56 berries separated into two groups of 28 berries. In the first group, the pathogen was applied $1 \mathrm{~h}$ after the yeast suspension, and the second group was inoculated $24 \mathrm{~h}$ after the yeast was applied. In both cases, pathogen inoculation was carried out by aspersion with $2.5 \mathrm{~mL}$ of suspended conidia (1 $\times 10^{6}$ conidia $\mathrm{mL}^{-1}$ ) at $30 \mathrm{~cm}$ from the berries using a manual sprayer. Yeast suspension in the control treatment was replaced by sterile distilled water. Three replicates per treatment were established. Berries were placed homogeneously on plastic trays with paper moistened with sterile distilled water, covered with plastic bags to maintain a high relative humidity, and incubated at 25 ${ }^{\circ} \mathrm{C}$ for $7 \mathrm{~d}$. After incubation, berries were checked with a stereomicroscope to verify the presence of $B$. cinerea. Disease incidence was calculated as a percentage of infected berries divided by the total berries analyzed per treatment.

\section{Identification of yeast with greater biocontrol activity}

To identify yeast showing greater antagonistic activity against $B$. cinerea, DNA was extracted from pure cultures with the Qiagen DNeasy Plant Mini Kit (Quiagen, Hilden, Germany) following manufacturer's instructions. One micro liter of DNA was suspended in a final volume of $50 \mu \mathrm{L}$ Polymerase Chain Reaction (PCR) reaction mixture containing $0.5 \mu \mathrm{M}$ ITS1 (5 TCCGTAGGTGAACCTGCGG 3') primer, $0.5 \mu \mathrm{M}$ of ITS4 (5 TCCTCCGCTTATTGATATGC 3`) primer, 0.2 $\mu \mathrm{M}$ deoxynucleotide, $1.5 \mathrm{mM} \mathrm{MgCl} 2$ and $1 \mathrm{x}$ buffer, and one unit of polymerase DNA (Invitrogen). PCR conditions were: $95{ }^{\circ} \mathrm{C}$ for $7 \mathrm{~min} ; 35$ cycles at $94{ }^{\circ} \mathrm{C}$ for $1 \mathrm{~min}, 55.5$ ${ }^{\circ} \mathrm{C}$ for $30 \mathrm{~s}$, and $72{ }^{\circ} \mathrm{C}$ for $1 \mathrm{~min}$, as well as a final step at $72{ }^{\circ} \mathrm{C}$ for $10 \mathrm{~min}$. The PCR products were separated in a $1 \%$ agarose gel with $0.5 \times$ TBE buffer $(45 \mathrm{mM}$ Trisborate, $1 \mathrm{mM}$ EDTA, and $\mathrm{pH}$ 8). After electrophoresis, the gel was dyed with ethidium bromide and visualized under UV light. The PCR products were sequenced by Macrogen Inc. (Seoul, Korea). Sequence analysis results of antagonistic yeast were aligned with the published full length sequences in the Basic Local Alignment Search Tool (BLAST) databases (National Center for Biotechnology Information [NCBI], US National Library of Medicine, Bethesda, Maryland, USA).

\section{Experimental design and statistical analysis}

The experiments were conducted in a complete randomized design with three replicates. All data were analyzed by ANOVA, multiple comparisons with the Duncan Test, and evaluated at $\alpha=0.05$. Analyses were performed with Statgraphics Plus ${ }^{\circledR}$ 5.0. To determine $\mathrm{EC}_{90}$, data were subjected to a Probit analysis with the Polo Plus v2.0 computer program.

\section{RESULTS AND DISCUSSION}

\section{Yeast isolation and selection}

A total of 256 grapevine epiphytic yeasts were obtained. These were placed in the microorganism collection of the Faculty of Agronomy of the Universidad de Concepción and kept at $4{ }^{\circ} \mathrm{C}$. Figure 1 shows the number of yeast isolates obtained from each table grape cultivar classified according to the scale proposed by Swadling and Jeffries (1996). Of the total yeast isolates, 32 were able to generate an inhibitory halo $>4 \mathrm{~mm}$ with the pathogen in dual cultures, which represent $12.5 \%$ of the total isolates. Yeasts with antagonistic activity on B. cinerea were obtained from the three analyzed table grape cultivars (Figure 1). Inhibition zones in the dual cultures could be due to the production of antibiotics, siderophores, toxic or antifungal metabolites used by these organisms as biological control mechanisms, and the size of the observed inhibition zones would represent the concentration and diffusivity of the inhibitory compounds secreted by each isolate (Swadling and Jeffries, 1996). However, production of these compounds in the culture media is not indicative of its production in action sites on the fruits (Dal Bello et al., 2008).

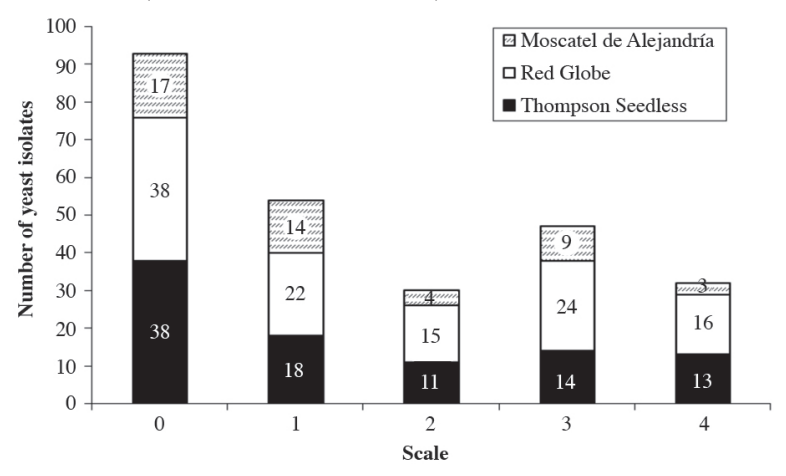

Figure 1. Antagonistic activity of yeasts isolated from grape cuticles against Botrytis cinerea in dual culture according to the scale: $0=$ no visible signs of $B$. cinerea inhibition and mycelium surpassed the yeast colony; 1 = both organisms stopped growing on contact; 2 = inhibition zone between pathogen and antagonist $<2 \mathrm{~mm} ; 3=$ inhibition zone 2 to 4 $\mathrm{mm} ; 4$ = inhibition zone $>4 \mathrm{~mm}$. 
Inhibitory effect of yeast isolates on $\boldsymbol{B}$. cinerea conidial germination

Eight of the 32 selected yeast isolates in the previous experiment (032a1, 058a3, 087a2, 100b1, 101b2, 156a3, $156 \mathrm{a} 5$, and $174 \mathrm{~b} 1)$ were able to inhibit $B$. cinerea conidial germination with a GII greater than $90 \%$ at both 5 and 25 ${ }^{\circ} \mathrm{C}$ (Figure 2). This inhibition could be due to different action mechanisms exerted by the yeasts. One of them could be the competition for nutrients since it has been reported that $B$. cinerea conidial germination is dependent on the amount of nutrients from the environment (Filonow et al., 1996). Another mechanism could be parasitism and/or production of enzymes that degrade the pathogen wall, such as glucanases; these are responsible for the degradation of cellulose and hemicellulose that are polymers making up the conidial walls (Masih and Paul, 2002).

\section{Yeast pathogenicity on table grape berries}

Of the eight previously selected yeast isolates, two of them (058a3 and 100b1) exhibited a damaging effect when they were inoculated on table grape berries cv. Flame Seedless by observing a soft consistency and tissue disintegration. This pathogenic characteristic contrasts with the objectives of this study; these isolates were therefore discarded for the following bioassays.

Yeast pathogenic aggressiveness can be related to the ability that some exhibit to develop forms of mycelial growth because they can invade plant tissues more rapidly and allow greater surface contact with the substrate (Gognies et al., 2001). There are various yeast species described as pathogenic for table grapes being Pichia, Brettanomyces, Cryptococcus, and Rhodotorula the most studied (Gognies et al., 2006). Even Saccharomyces cerevisiae, the most researched fermentative yeast, can also act as a pathogen on plants causing delay in their growth or death (Gognies et al., 2001).

\section{Effect of yeast concentration and colonization time}

When evaluating the effects of increasing antagonistic yeast concentrations on the inhibition of $B$. cinerea conidial germination, it was observed that there is a dosedependent response. As yeast concentration increased, inhibition of $B$. cinerea conidial germination increased (Figure 3). The values of $\mathrm{EC}_{90}$ fluctuated between $0.45 \times$ $10^{5}$ and $0.22 \times 10^{8}$ cells $\mathrm{mL}^{-1}$ (Table 1 ), and isolate $156 \mathrm{a} 5$ was noted for the lowest $\mathrm{EC}_{90}\left(0.45 \times 10^{5}\right.$ cells $\left.\mathrm{mL}^{-1}\right)$.

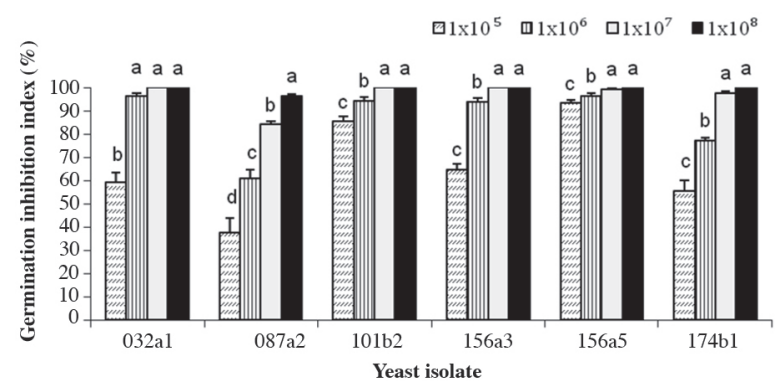

Different letters over the bars indicate significant differences between different concentrations for the same isolate according to Duncan test $(\mathrm{P}<0.05)$.

Figure 3. Germination inhibition index of Botrytis cinerea treated with different concentrations of antagonistic yeast.

Table 1. Effective concentration $\left(\mathrm{EC}_{90}\right)$ values of yeast applied to Botrytis cinerea conidia.

\begin{tabular}{lcccc}
\hline $\begin{array}{l}\text { Yeast } \\
\text { isolate }\end{array}$ & $\mathrm{EC}_{90}\left(\right.$ cell $\left.\mathrm{mL}^{-1}\right)(95 \% \mathrm{FL})$ & Slope $\pm \mathrm{SE}$ & $\begin{array}{c}\text { Chi square } \\
\left(\chi^{2}\right)\end{array}$ & df \\
\hline $032 \mathrm{a} 1$ & $0.47 \times 10^{6}\left(0.37 \times 10^{6}\right.$ to $\left.0.63 \times 10^{6}\right)$ & $1.56 \pm 0.131$ & 24.99 & 22 \\
$087 \mathrm{a} 2$ & $0.22 \times 10^{8}\left(0.14 \times 108\right.$ to $\left.0.39 \times 10^{8}\right)$ & $0.66 \pm 0.043$ & 26.20 & 20 \\
$101 \mathrm{~b} 2$ & $0.23 \times 10^{6}\left(0.14 \times 10^{6}\right.$ to $\left.0.34 \times 10^{6}\right)$ & $0.76 \pm 0.095$ & 23.10 & 22 \\
$156 \mathrm{a} 3$ & $0.54 \times 10^{6}\left(0.43 \times 10^{6}\right.$ to $\left.0.72 \times 10^{6}\right)$ & $1.24 \pm 0.108$ & 14.39 & 22 \\
$156 \mathrm{a} 5$ & $0.45 \times 10^{5}\left(0.10 \times 10^{5}\right.$ to $\left.1.01 \times 10^{5}\right)$ & $0.50 \pm 0.091$ & 17.75 & 22 \\
$174 \mathrm{~b} 1$ & $0.24 \times 10^{7}\left(0.17 \times 10^{7}\right.$ to $\left.0.38 \times 10^{7}\right)$ & $0.89 \pm 0.061$ & 31.81 & 22 \\
\hline
\end{tabular}

FL: fiducial limits; SE: standard error.

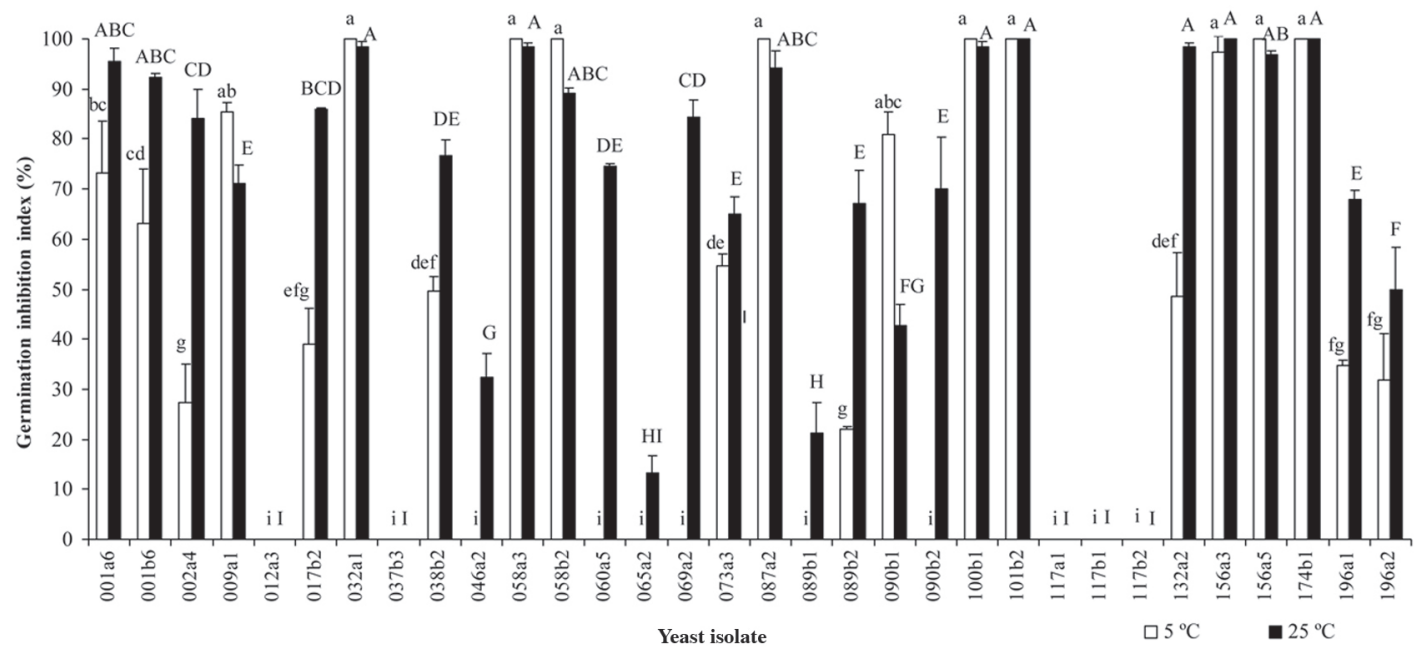

Different lower-case letters indicate significant differences according to Duncan test $(\mathrm{P}<0.05)$. Different upper-case letters indicate significant differences according to Duncan test $(\mathrm{P}<0.05)$.

Figure 2. Germination inhibition index of Botrytis cinerea treated with different yeast isolates at 5 and $25^{\circ} \mathrm{C}$. 
Inhibition of $B$. cinerea conidial germination could be due to the parasitism exerted by the yeast (Wisniewski et al., 1991) and enzyme action, such as quitinases and $\beta-1,3$ glucanases, which degrade the $B$. cinerea cell wall and produce cytological damage (El-Ghaouth et al., 1998; Rabosto et al., 2006).

In the berries treated with yeasts, whether 1 or $24 \mathrm{~h}$ before inoculation with the pathogen, the incidence of gray mold decreased in relation to the control (Figure 4). The lowest incidence was obtained when yeast were applied $24 \mathrm{~h}$ before inoculation of the pathogen and the $101 \mathrm{~b} 2,156 \mathrm{a} 3$, and $156 \mathrm{a} 5$ isolates were able to reduce gray mold incidence up to approximately $80 \%$ as compared to the control; these were considered as the best controllers of gray mold under the study conditions. Similar results were reported by Raspor et al. (2010), who obtained a significant decrease in the degree of infection of $B$. cinerea on grapes treated with yeast $24 \mathrm{~h}$ before inoculation with $B$. cinerea as compared to grapes treated with yeast and immediately inoculated with the pathogen. This increase in yeast biocontrol activity as determined by a greater colonization time in the berry wounds could be due to a greater yeast proliferation with subsequent better colonization of the wounds enabling it to compete with the pathogen for space and nutrients (Filonow et al., 1996; Saligkarias et al., 2002).

\section{Identifying yeast with greater biocontrol activity}

In order to identity the $101 \mathrm{~b} 2,156 \mathrm{a} 3$, and $156 \mathrm{a} 5$ antagonistic yeast, the PCR products were sequenced (Macrogen Inc.) and compared to the sequences deposited in the GenBank database. For the three antagonistic yeasts, 99\% similarity was obtained with the published sequences for Issatchenkia terricola (Accession No AY235808.1). Antagonistic activity of $I$. terricola yeast isolated from grapes was reported by Bleve et al. (2006); in such study, I. terricola reduced Aspergillus carbonarius and A. niger colonization on grape berries.

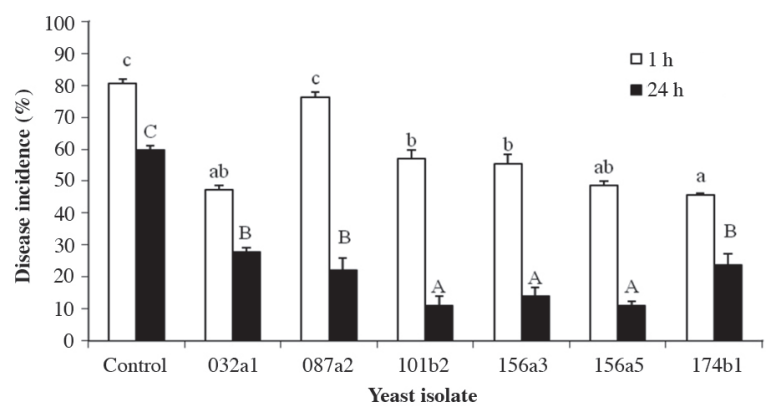

Different lower-case letters indicate significant differences according to Duncan test $(\mathrm{P}<$ $0.05)$. Different upper-case letters indicate significant differences according to Duncan test $(\mathrm{P}<0.05)$.

Figure 4. Gray mold incidence in grape berries treated with antagonistic yeast 1 or 24 h before Botrytis cinerea inoculation.

\section{CONCLUSIONS}

In accordance with the conditions established in this study, we can conclude that grapevine epiphytic yeasts exhibit antagonistic activity on Botrytis cinerea. There is a direct relationship between the concentration of the antagonist and the inhibition of in vitro germination of $B$. cinerea conidia; a longer yeast colonization time on the berries decreases the incidence of gray mold. Our results confirm the effectiveness of epiphytic yeasts as biocontrol agents of gray mold, which is one of the most damaging diseases for agricultural plants.

\section{ACKNOWLEDGEMENTS}

This study was funded by the Fondo Nacional de Desarrollo Científico y Tecnológico (FONDECYT Project $N^{\circ} 11080062$ ).

Aislación y selección de levaduras epífitas para el biocontrol de Botrytis cinerea Pers. en uva de mesa. Botrytis cinerea Pers., agente causal de la pudrición gris, infecta a más de 200 especies vegetales. Tradicionalmente, este patógeno ha sido controlado con fungicidas; sin embargo, la creciente demanda de alimentos libres de pesticidas hace necesario el uso de nuevas estrategias de control. El objetivo de este estudio fue aislar y seleccionar levaduras epífitas de vid (Vitis vinifera L.) para el biocontrol de $B$. cinerea en uva de mesa. Del total de levaduras aisladas $(n=256), 32$ presentaron inhibición del crecimiento micelial, en cultivos duales, con un halo $>4$ mm y ocho de estos aislamientos inhibieron la germinación de conidias $>90 \%$. Al evaluar concentraciones crecientes de levaduras sobre la inhibición de la germinación de conidias, se observó una respuesta dosis-dependiente, con valores de $\mathrm{CE}_{90}$ de $0,45 \times 10^{5}$ a $0,22 \times 10^{8}$ células $\mathrm{mL}^{-1}$. Al evaluar la actividad antagonista de seis levaduras frente a $B$. cinerea en bayas de uva de mesa 'Flame Seedless' se determinó que al aumentar el tiempo de colonización de las levaduras en las bayas de 1 a 24 h, la actividad de biocontrol sobre $B$. cinerea fue superior. Estos resultados demuestran la efectividad de levaduras epífitas de vid como agentes de biocontrol de $B$. cinerea en uva de mesa.

Palabras clave: pudrición gris, levaduras antagonistas, agentes de biocontrol, Vitis vinifera.

\section{LITERATURE CITED}

Agrios, G.N. 2005. Plant pathology. $5^{\text {th }}$ ed. Elsevier Academic Press, Burlington, Massachusetts, USA.

Benito, E., M. Arranz, y A. Eslava. 2000. Factores de patogenicidad de Botrytis cinerea. Revista Iberoamericana de Micología 17(Suppl.):S43-S46.

Bleve, G., F. Grieco, G. Cozzi, A. Logrieco, and A. Visconti. 2006. Isolation of epiphytic yeasts with potential for biocontrol of Aspergillus carbonarius and A. niger on grape. International Journal of Food Microbiology 108:204-209. 
Chanchaichaovivat, A., P. Ruenwongsa, and B. Panijpan. 2007. Screening and identification of yeast strains from fruits and vegetables: potential for biological control of postharvest chilli anthracnose (Colletotrichum capsici). Biological Control 42:326-335.

Dal Bello, G., C. Mónaco, C. Rollan, G. Lampugnani, N. Arteta, C. Abramoff, et al. 2008. Biocontrol of postharvest grey mould on tomato by yeasts. Journal of Phytopathology 156(5):257-263.

Droby, S., L. Cohen, A. Daus, B. Weiss, B. Horev, E. Chalutz, et al. 1998. Commercial testing of Aspire: A yeast preparation for the biological control of postharvest decay of citrus. Biological Control 12(2):97-101.

Elad, Y., B. Williamson, P. Tudzynski, and N. Delen. 2007. Botrytis spp. and diseases they cause in agricultural systems - an introduction. p. 1-8. In Elad, Y., B. Williamson, P. Tudzynski, and N. Delen (eds.) Botrytis: biology, pathology and control. Kluwer Academic Publishers, Dordrecht, The Netherlands.

El-Ghaouth,A.,Ch.Wilson, and M. Wisniewski.1998. Ultrastructural and cytochemical aspects of the biological control of Botrytis cinerea by Candida saitoana in apple fruit. Phytopathology 88:282-291.

Elmer, P.A.G., and T. Reglinski. 2006. Biosuppression of Botrytis cinerea in grapes. Plant Pathology 55:155-177.

Esterio, M., J. Auger, C. Ramos, and H. García. 2007. First report of fenhexamid resistant isolates of Botrytis cinerea on grapevine in Chile. Plant Disease 91(6):768.

Filonow, A.B., H.S. Vishniac, J.A. Anderson, and W.J. Janisiewicz. 1996. Biological control of Botrytis cinerea in apple by yeasts from various habitats and their putative mechanisms of antagonism. Biological Control 7:212-220.

Gognies, S., E.A. Barka, A. Gainvors-Claisse, and A. Belarbi. 2006. Interactions between yeasts and grapevines: filamentous growth, endopolygalacturonase and phytopathogenicity of colonizing yeasts. Microbial Ecology 51:109-116.

Gognies, S., A. Belarbi, and E.A. Barka. 2001. Saccharomyces cerevisiae, a potential pathogen towards grapevine, Vitis vinifera. FEMS Microbiology Ecology 37:143-150.

Holz, G., M. Gütschow, S. Coertze, and F.J. Calitz. 2003. Occurrence of Botrytis cinerea and subsequent disease expression at different positions on leaves and bunches of grape. Plant Disease 87(4):351358.

Latorre, B.A. 2004. Enfermedades de las plantas cultivadas. $6^{\text {a }}$ ed. Ediciones Universidad Católica, Santiago, Chile.

Latorre, B.A. 2007. Pudrición gris (Botrytis cinerea), un factor limitante de la producción de uva de mesa en Chile. Fitopatología 42:9-20.

Latorre, B.A., C. Lillo, y M.E. Rioja. 2001. Eficacia de los tratamientos fungicidas para el control de Botrytis cinerea de la vid en función de la época de aplicación. Ciencia e Investigación Agraria 28(2):61-66.

Latorre, B.A., I. Spadaro, and M.E. Rioja. 2002. Occurrence of resistant strains of Botrytis cinerea to anilinopyrimidine fungicides in table grapes in Chile. Crop Protection 21(10):957-961.

Manici, L., L. Lazzeri, and S. Palmieri. 1997. In vitro fungitoxic activity of some glucosinolates and their enzyme-derived products toward plant pathogenic fungi. Journal of Agricultural and Food Chemistry 45:2768-2773.

Masih, E., and B. Paul. 2002. Secretion of $\beta-1,3$-glucanases by the yeast Pichia membranifaciens and its possible role in the biocontrol of Botrytis cinerea causing grey mold disease of the grapevine. Current Microbiology 44(6):391-395.
McLaughlin, R.J., C.L. Wilson, E. Chalutz, C.P. Kurtzman, W.F. Fett, and S.F. Osman. 1990. Characterization and reclassification of yeasts used for biological control of postharvest diseases of fruits and vegetables. Applied and Environmental Microbiology 56:3583-3586.

Rabosto, X., M. Garrau,A.Paz,E. Boido,E. Dellacassa, and F. Carrau. 2006. Grapes and vineyard soils as source of microorganisms for biological control of Botrytis cinerea. American Journal of Enology and Viticulture 57:332-338.

Raspor, P., D. Miklič-Milek, M. Avbelj, and Neža Čadež. 2010. Biocontrol of grey mould disease on grape caused by Botrytis cinerea with autochthonous wine yeasts. Food Technology and Biotechnology 48:336-343.

Saligkarias, I.D., F.T. Gravanis, and H.A.S. Epton. 2002. Biological control of Botrytis cinerea on tomato plants by the use of epiphytic yeasts Candida guilliermondii strains 101 and US 7 and Candida oleophila strain I-182: I. In vivo studies. Biological Control 25:143-150.

Santos, A., A. Sánchez, and D. Marquina. 2004. Yeasts as biological agents to control Botrytis cinerea. Microbiological Research 159(4):331-338.

Serey, R.A., R. Torres, and B.A. Latorre. 2007. Pre- and postinfection activity of new fungicides against Botrytis cinerea and other fungi causing decay of table grapes. Ciencia e Investigación Agraria 34:215-224.

Sharma, R.R., D. Singh, and R. Singh. 2009. Biological control of postharvest diseases of fruits and vegetables by microbial antagonists: a review. Biological Control 50:205-221.

Spadaro, D., and M.L. Guillino. 2003. State of the art and future prospects of the biological control of postharvest fruit diseases. International Journal of Food Microbiology 91:185-194.

Spadaro, D., R. Vola, S. Piano, and M.L. Gullino. 2002. Mechanisms of action and efficacy of four isolates of the yeast Metschnikowia pulcherrima active against postharvest pathogens on apples. Postharvest Biology and Technology 24:123-134.

Swadling, I., and P. Jeffries. 1996. Isolation of microbial antagonists for biocontrol of grey mould disease of strawberries. Biocontrol Science and Technology 6:125-136.

Vero, S., P. Mondino, J. Burgueño, M. Soubes, and M. Wisniewski. 2002. Characterization of biocontrol activity of two yeast strains from Uruguay against blue mold of apple. Postharvest Biology and Technology 26:91-98.

Viret, O., M. Keller, V.G. Jaudzems, and F.M. Cole. 2004. Botrytis cinerea infection of grape flowers: light and electron microscopical studies of infection sites. Phytopathology 94:850-857.

Williamson, B., B. Tudzynski, P. Tudzynski, and J. Van Kan. 2007. Botrytis cinerea: the cause of grey mould disease. Molecular Plant Pathology 8:561-580.

Wisniewski, M., C. Biles, S. Droby, R. McLaughlin, C. Wilson, and E. Chalutz. 1991. Mode of action of the postharvest biocontrol yeast Pichia guilliermondii. I. Characterization of the attachment to Botrytis cinerea. Physiological and Molecular Plant Pathology 39:245-258

Zahavi, T., L. Cohen, B. Weiss, L. Schena, A. Daus, T. Kaplunov, et al. 2000. Biological control of Botrytis, Aspergillus and Rhizopus rots on table and wine grapes in Israel. Postharvest Biology and Technology 20:115-124.

Zhang, H., L. Wang, Y. Dong, S. Jiang, J. Cao, and R. Meng. 2007. Postharvest biological control of gray mold decay of strawberry with Rhodotorula glutinis. Biological Control 40:287-292. 